\title{
Radiographic features of pulmonary tuberculosis in patients infected by HIV: is there an objective indicator of co-infection?
}

\author{
Características radiológicas da tuberculose pulmonar em doentes infectados \\ pelo HIV: existe um indicador objetivo da co-infecção?
}

\author{
Maria de Fátima Militão de Albuquerque', Silvio Cavalcanti de Albuquerque', \\ Antonio Roberto Leite Campelo', Marta Cruz', Wayner V. de Souza², \\ Ricardo A.A. Ximenes ${ }^{1}$ and Roberta A.S. de Souza ${ }^{1}$
}

\begin{abstract}
This study aimed to compare the radiographic characteristics of patients with pulmonary tuberculosis (TB) and human immunodeficiency virus (HIV) infection with those of HIV-negative patients. In all, 275 TB patients attending the outpatients clinics at the University Hospital/UFPE, were studied from January 1997 to March 1999. Thirty nine (14.2\%) of them were $\mathrm{HIV}^{+}$, with a higher frequency of males in this group $(p=0.044)$. Seventy-five percent of the HIV+ patients and $19 \%$ of the HIV had a negative tuberculin test $(P P D)(p<0.001)$. The proportion of positive sputum smears in the two groups was similar. The radiological finding most strongly associated with co-infection was absence of cavitation $(p<0.001)$. It may therefore be concluded that the lack of cavitation in patients with pulmonary TB may be considered a useful indicator of the need to investigate HIV infection. This approach could contribute to increasing the effectiveness of local health services, by offering appropriate treatment to co-infected patients.
\end{abstract}

Key-words: Tuberculosis. HIVIAIDS. Radiographic features.

Resumo Este trabalho objetivou comparar características radiológicas de doentes com tuberculose (TB) pulmonar, soropositivos para o vírus da imunodeficiência humana (HIV), com aquelas de doentes HIV. Estudouse, prospectivamente, 275 doentes com TB pulmonar, atendidos no Hospital das Clínicas da UFPE, entre janeiro de 1997 e março de 1999. Destes, $39(14,2 \%)$ eram HIV+, com um predomínio maior de homens neste grupo $(p=0,044)$. Setenta e cinco por cento dos doentes HIV+ e $19 \%$ dos HIV apresentavam reação negativa ao teste tuberculínico $(P P D)(p<0,001)$. A proporção de baciloscopias positivas nos dois grupos foi semelhante. A característica radiológica mais fortemente associada à co-infecção tuberculose pulmonar/HIV+ foi a ausência de cavidades $(p<0,001)$. Conclui-se que, diante de doentes com TB pulmonar, a ausência de cavidades na telerradiografia de tórax constitui-se num indicador útil da necessidade de se investigar a infecção pelo HIV. Esta conduta pode contribuir para aumentar a efetividade dos serviços locais de saúde, permitindo oferecer tratamento adequado a estes doentes.

Palavras-chaves: Tuberculose. HIV/AIDS. Achados radiológicos.

The pandemic of the Human Immunodeficiency Virus (HIV) has been pointed out as one of the major causes of the worldwide increase in tuberculosis cases. This is due to the fact that tuberculosis is one of the most common infections to occur in the course of HIV infection, either because of the reactivation of latent TB or as a result of new infection by the tuberculosis mycobacterium, with a faster progression towards the active disease. When tuberculosis is associated with HIV infection, the difficulty in establishing a diagnosis using traditional parameters contributes to the resurgence of this disease ${ }^{12}$.
In Brazil, as in most developing countries, the diagnosis of pulmonary tuberculosis depends on the clinical symptoms, chest radiography, tuberculin test and sputum smear examination for acid-fast bacilli (AFB). The culture for M. tuberculosis is not routinely performed due to the cost and delay in obtaining results ${ }^{11}$. In cases of pulmonary tuberculosis associated with HIV infection, the results of these examinations are often uncharacteristic, which delays the diagnosis ${ }^{15}$. At present, HIV testing is not routinely carried out on all tuberculosis patients ${ }^{8}$.

\footnotetext{
1.Departamento de Clínica Médica da Universidade Federal de Pernambuco, Recife, PE.2. Centro de Pesquisas Aggeu Magalhães da Fundação Oswaldo Cruz. Recife, PE. Suporte Financeiro: FACEPE.

Address to: Dra. Maria de Fátima Militão Albuquerque. Depto de Clínica Médica/Hospital das Clínicas/UFPE. Av. Prof. Moraes Rêgo s/n, Bloco A, Cidade Universitária,50670-420 Recife, PE.

Recebido para publicação em 21/9/2000.
} 
However, the relatively high frequency of HIV infection among new cases of tuberculosis in some Brazilian cities $(9.6 \%)$ indicates the need to investigate the presence of this association, in order to offer these patients appropriate treatment for both infections ${ }^{10}$. In 1996, it was estimated that in Brazil the greater number of individuals infected by HIV would result in a $20 \%$ increase in the incidence of tuberculosis by the end of the decade.
Among the diagnostic tools traditionally used for the diagnosis of pulmonary tuberculosis, the chest $x$-ray plays a fundamental role, mainly because it is widely available within the public health system, even in poor areas. The study of the radiographic features of pulmonary tuberculosis associated with HIV infection is therefore justified in seeking objective indicators that may suggest a higher probability of the presence of co-infection.

\section{MATERIAL AND METHODS}

All patients diagnosed as having pulmonary tuberculosis who attended the tuberculosis out-patients clinic at the University Hospital of the Federal University of Pernambuco (HC/UFPE) from January 1997 to May 1999, who had a chest X-ray taken and anti-HIV test performed were studied prospectively. All the patients had three sputum smear exams for acid-fast bacilli carried out using the Ziehl-Neelsen technique. The tuberculin test was performed with $0.1 \mathrm{ml}$ of PPD RT23, according to a standardized technique.

The chest radiographs were analyzed by a single radiologist of the HC/UFPE, a member of the research team, who filled out a standardized form. The radiographic features were summarized in categories previously discussed (as described in Table 2). The radiologist was aware neither of the HIV status of the patient nor the previous radiographic reading, carried out by another radiologist from the hospital staff.

ELISA 1 and 2, immunofluorescence and Westernblot techniques were used for the diagnosis of HIV. When ELISA 1 and 2 tests were negative the result was considered as non-reagent. Those that were positive for ELISA 1 and 2 underwent an immunofluorescence test and when positive were considered as reagent.

The association between the clinical and radiographic characteristics and the result of the antiHIV test was studied and the significance of this association was tested by the chi-square or Fisher test, when indicated, and the $\mathrm{p}$-value.

\section{RESULTS}

Two hundred and seventy-five (275) patients with a diagnosis of pulmonary tuberculosis met the inclusion criteria. Thirty-nine (14.2\%) of these were $\mathrm{HIV}^{+}$, with a significantly larger proportion of men among $\mathrm{HIV}^{+}$ patients than among HIV- $(p=0.044)$, whilst the age distribution of the two groups was similar (Table 1).
Seventy-five percent $(75 \%)$ of the $\mathrm{HIV}^{+}$patients had a negative tuberculin test $(\mathrm{PPD}=0 \mathrm{~mm})$, compared with $19 \%$ (36 out of 189) of the HIV- patients ( $p<0.001)$. There was no statistically significant association between the result of the sputum smear examination and the result of the HIV test $(p=0.188)$.

Table 1- Demographic and clinical characteristics of 275 pulmonary tuberculosis patients HIV+and HIV-, Hospital das Clínicas - UFPE, January 1997 to March 1999.

\begin{tabular}{|c|c|c|c|c|c|}
\hline \multirow[t]{2}{*}{ Characteristics } & \multicolumn{2}{|c|}{$\mathrm{HIV}^{+}$} & \multicolumn{2}{|c|}{$\mathrm{HIV}^{-}$} & \multirow[b]{2}{*}{ P-value } \\
\hline & $\mathrm{n}$ & $\%$ & $\mathrm{n}$ & $\%$ & \\
\hline \multicolumn{6}{|l|}{ Sex } \\
\hline Male & 30 & 76.9 & 138 & 58.5 & 0.044 \\
\hline Female & 9 & 23.1 & 98 & 41.5 & \\
\hline Total & 39 & 100.0 & 236 & 100.0 & \\
\hline \multicolumn{6}{|c|}{ Age group (years) } \\
\hline $0-14$ & - & - & 08 & 3.4 & \\
\hline $15-34$ & 23 & 59.0 & 100 & 42.6 & \\
\hline $35-44$ & 9 & 23.1 & 61 & 26.0 & 0.179 \\
\hline $45-64$ & 7 & 17.9 & 50 & 21.3 & \\
\hline$\geq 65$ & - & - & 16 & 6.8 & \\
\hline Total & 39 & 100.0 & 236 & 100.0 & \\
\hline \multicolumn{6}{|c|}{ Response to the Tuberculin Test (PPD) } \\
\hline non reagent & 21 & 75.0 & 36 & 19.0 & $<0.001$ \\
\hline$\geq 5 \mathrm{~mm}$ & 7 & 25.0 & 153 & 81.0 & \\
\hline Total & 28 & 100.0 & 189 & 100.0 & \\
\hline \multicolumn{6}{|c|}{ Ziehl-Neelson acid-fast stain } \\
\hline Positive & 18 & 56.3 & 145 & 69.7 & 0.188 \\
\hline Negative & 14 & 43.8 & 63 & 30.3 & \\
\hline Total & 32 & 100.0 & 208 & 100.0 & \\
\hline
\end{tabular}


Table 2 shows the radiological findings of the 275 pulmonary tuberculosis patients. Focal infiltrate was the most frequent radiographic pattern observed.

The chest radiographic findings were grouped into eight categories: normal, focal infiltrate, diffuse infiltrate, pulmonary nodules, miliary disease, lymphadenopathy, pleural effusion and absence of cavities and the results presented according to the HIV status. It was found that absence of cavities was significantly associated with HIV infection $(p<0.001)$ (Table 3).

\begin{tabular}{|c|c|c|}
\hline Radiological pattern & $\mathrm{N}$ & $\%$ \\
\hline Normal & 17 & 3.6 \\
\hline Focal infiltrate & 189 & 40.4 \\
\hline Diffuse infiltrate & 26 & 5.6 \\
\hline Single cavity & 57 & 12.2 \\
\hline Multiple cavities & 67 & 14.3 \\
\hline Miliary & 7 & 1.5 \\
\hline Nodules & 6 & 1.3 \\
\hline Lymphadenopathy & 12 & 2.6 \\
\hline Pleural effusion & 25 & 5.3 \\
\hline Others & 62 & 13.2 \\
\hline Total & 468 & 100.0 \\
\hline
\end{tabular}

Table 3 - Radiological patterns of pulmonary tuberculosis patients $\mathrm{HIV}^{+}$and $\mathrm{HIV}^{-}$ Hospital das Clínicas - UFPE, January 1997 to March 1999.

\begin{tabular}{|c|c|c|c|c|c|}
\hline \multirow[b]{2}{*}{ Radiological pattern } & \multicolumn{2}{|c|}{$\mathrm{HIV}^{+}$} & \multicolumn{2}{|c|}{$\mathrm{HIV}^{-}$} & \multirow[b]{2}{*}{ P-value } \\
\hline & $\mathrm{n}$ & $\%$ & $\mathrm{n}$ & $\%$ & \\
\hline Normal & 3 & 7.7 & 14 & 5.9 & $\mathrm{p}=0.717^{*}$ \\
\hline Focal infiltrate & 24 & 61.5 & 165 & 69.9 & $\mathrm{p}=0.390^{* *}$ \\
\hline Diffuse Infiltrate & 2 & 5.1 & 24 & 10.2 & $\mathrm{p}=0.552^{*}$ \\
\hline Nodules & - & - & 7 & 2.9 & $p=0.598^{*}$ \\
\hline Miliary & 3 & 7.7 & 4 & 1.7 & $\mathrm{p}=0.061^{*}$ \\
\hline Lymphadenopathy & 4 & 10.3 & 8 & 3.4 & $\mathrm{p}=0.073^{*}$ \\
\hline Pleural effusion & 6 & 15.4 & 19 & 8.1 & $p=0.141^{*}$ \\
\hline Absence of cavities & 32 & 82.1 & 119 & 50.4 & $\mathrm{p}=0.0005^{\star *}$ \\
\hline
\end{tabular}

*Fisher exact test

${ }^{* *} \mathrm{Cc}^{2}$ Yates

\section{DISCUSSION}

There seems to be a consensus regarding the modifications of the clinical-epidemiological pattern of pulmonary tuberculosis when associated with HIV infection. Traditional diagnostic methods to a certain extent lose their specificity ${ }^{15}$, thus necessitating the redefinition of their characteristics.

Regarding the age group, although a larger concentration of cases of co-infection among the individuals aged 20 to 39 years $(74.4 \%$ of the cases) was observed, there was no statistically significant difference in the age distribution between the two groups $\mathrm{HIV}^{+}$and $\mathrm{HIV}^{-}$.

The difference in the frequency of patients with pulmonary tuberculosis associated with $\mathrm{HIV}^{+}$between sexes and age groups depends on the specific prevalence of both infections by sex and age in the population. Pozniak et $a^{{ }^{15}}$ found in Zimbabwe, Africa, that the distribution of co-infection by sex was similar, whilst Awil et al', in another area of Africa (Gulu, Uganda) described a higher frequency of co-infection among women. In the present study there was a larger proportion of males among those infected by HIV ( $p=0.044)$.

With respect to age distribution, there is an overlap of the population groups affected by both infections. The prevalence of tuberculosis is greater among young adults, and the individuals most frequently affected by HIV infection are aged 15 to 49 years ${ }^{2}$. A survey carried out in Rio de Janeiro showed that the highest frequency of HIV infection among tuberculosis patients, $7.4 \%$, was found in the 15 to 39 age group 7 . In this study a larger number of individuals in the 15 to 34 age group was found among co-infected patients (59\%), but a similar finding was observed in those with only pulmonary tuberculosis (Table 1).

The association found between a negative reaction to the tuberculin test (PPD=0mm) and a positive antiHIV test $(p<0.001)$ is in agreement with the literature ${ }^{15}$. 
In $\mathrm{HIV}^{+}$patients, due to the absence of delayed-type hypersensitivity response, lung cavitation is not usual, so the dissemination of bacilli may occur and result in atypical findings. Absence of cavitation has been related to a higher frequency of negative acid-fast bacilli sputum smears in co-infected patients ${ }^{6}{ }^{15}$. There was a similar proportion of positive sputum smears in the two groups in this study, which agrees with other reports in the literature ${ }^{4}$.

Some authors, analyzing the radiological pattern most frequently found among patients with pulmonary tuberculosis associated with HIV, describe the following features: hilar adenopathy, no cavitary infiltrates and miliary disease ${ }^{13} 141516$. In Brazil, few studies have been carried out with the objective of studying the radiographic pattern of pulmonary tuberculosis associated with HIV infection ${ }^{35917}$. Camera et $a^{\beta}$ found, in a retrospective study of 104 individuals with pulmonary tuberculosis $/ \mathrm{HIV}^{+}$, that the most frequent findings were interstitial infiltrate $(71.2 \%)$ and alveolar lesion (63.5\%). However, there was no comparison group i.e. HIV'individuals.

In the present study, the absence of cavities was the radiographic characteristic most strongly associated with co-infection. Miliary disease and lymphadenopathy were more frequent in the $\mathrm{HIV}^{+}$group, but the difference was not statistically significant, possibly due to the sample size. The small percentage of diffuse infiltrates among the $\mathrm{HIV}^{+}$ patients may be due to the low sensibility of conventional radiology in detecting early interstitial disease.

It may therefore be concluded that absence of cavities may be considered a useful indicator for the need to investigate HIV infection in patients with a clinical or bacteriological diagnosis of pulmonary tuberculosis. This approach could contribute to increasing the effectiveness of local health services, which diagnose and treat tuberculosis cases, by providing appropriate treatment for co-infected patients, in addition to orientating them to prevent HIV transmission.

\section{REFERENCES}

1. Awil PO, Bowlin SJ, Daniel TM. Radiology of pulmonary tuberculosis and human immunodeficiency virus infection in Gulu, Uganda. European Respiratory Journal 10: 615-618, 1997.

2. Barnes PF, Bloch AB, Davidson PT, Snider Jr DE. Tuberculosis in patients with human immunodeficiency virus infection. New England Journal of Medicine 324:1644-1650, 1991.

3. Camera CS, Santos AAS, Moraes APP, Silva WAE, Camisão CC, Oliveira CAB, Kischinhevski W. Radiologia do tórax em pacientes HIV-positivos com tuberculose; análise of 104 casos. Radiologia Brasileira 23: 241-247, 1990.

4. Finch $D$, Beaty $C D$. The utility of single sputum specimen in the diagnosis of tuberculosis. Comparison between HIV-infected and non-infected patients. Chest 111:1174-1179, 1999.

5. Henn L, Nagel F, Dal-Pizzol F. Comparison between human immunodeficiency virus positive and negative patients with tuberculosis in Southern Brazil. Memórias do Instituto Oswaldo Cruz 94: 377-381, 1999.

6. Jones BE, Ryu R, Yang Z, Dig MD, Pogoda JM, Otaya M, Barnes PF. Chest radiographic findings in patients with tuberculosis with recent or remote infection. American Jounal Respiratory and Critical Care Medicine 155: 1270-1273, 1997.

7. Kritski AL, Werneck-Barroso E, Vieira MA, Carvalho ACC, Carvalho CE, Bravo-de-Souza R, Andrade GD, I Galvão-Castro $B$, Castilho EA, Hearst N. HIV infection in 567 active pulmonary tuberculosis patients in Brazil. Journal of Acquired Immune Deficiency Syndrome 6:1008-1012, 1993.

8. Kumar D, Watson JM, Charlett A, Nicholas S, Darbyshire JH. Tuberculosis in England and Wales in 1993: results of a national survey. Thorax 52:1060-1067, 1997.

9. Kusano MS. Comparative study of patients with tuberculosis with and without HIV infection in the Federal District. Revista Brasileira de Enfermagem 49:41-54, 1996.
10. Lima MM, Belluomini M, Almeida MMB, Arantes GR. Co-infecção HIV/Tuberculose: necessidade de uma vigilância mais efetiva. Revista de Saúde Pública 31:217-220, 1997.

11. Ministério da Saúde. Manual de Normas de Tuberculose para o Controle da Tuberculose. Centro Nacional de Epidemiologia. $5^{a}$ edição, Coordenação Nacional de Pneumologia Sanitária.Brasília, DF.

12. Macadams HP, Erasmus J, Winter JA. Radiologic manifestation of pulmonary tuberculosis. Radiologic Clinics of North America, 33: 655-678, 1995

13. Perlman AD, El-Sadr WM, Nelson ET, Matts JP, Telzak EE, Salomon N, ChirgwiN K, Hafner R. Variation of chest radiographic patterns in pulmonary tuberculosis by degree of human immunodeficiency virus-related immunosuppression. Clinical Infection Diseases 25: 242-246, 1997.

14. Pitchenik $A E$, Rubinson HA. The radiographic appearance of tuberculosis in patients with the acquired Immune Deficiency Syndrome (AIDS) and Pre-AIDS. Journal Medicine 307: 162-165, 1982.

15. Pozniak AL, MacLeod GA, Ndlovu D, Ross E, Mahari M, Weinberg J. Clinical and Chest Radiographic Features of Tuberculosis associated with Human Immunodeficiency Virus in Zimbabwe. American Jounal Respiratory and Critical Care Medicine 152 :15581561, 1995.

16. Shah RM, Kaji AV, Ostrum BJ, Friedman BC. interpretation of chest radiographs in AIDS patients. Scientific Exhibit 17: 47-57, 1997.

17. Trajman A, Neto EB, Belo MT, Teixeira EG, Selig L, Ferrari G, Branco MM. Pleural tuberculosis and human immunodeficiency virus co-infection. International Journal of Tuberculosis and Lung Diseases 1: 487, 1997. 